\title{
EIDINOW, Esther and KINDT, Julia (eds.). The Oxford Handbook of Ancient Greek Religion. Oxford and New York: Oxford University Press, 2015. p. xxii +708. ISBN 9780199642038.
}

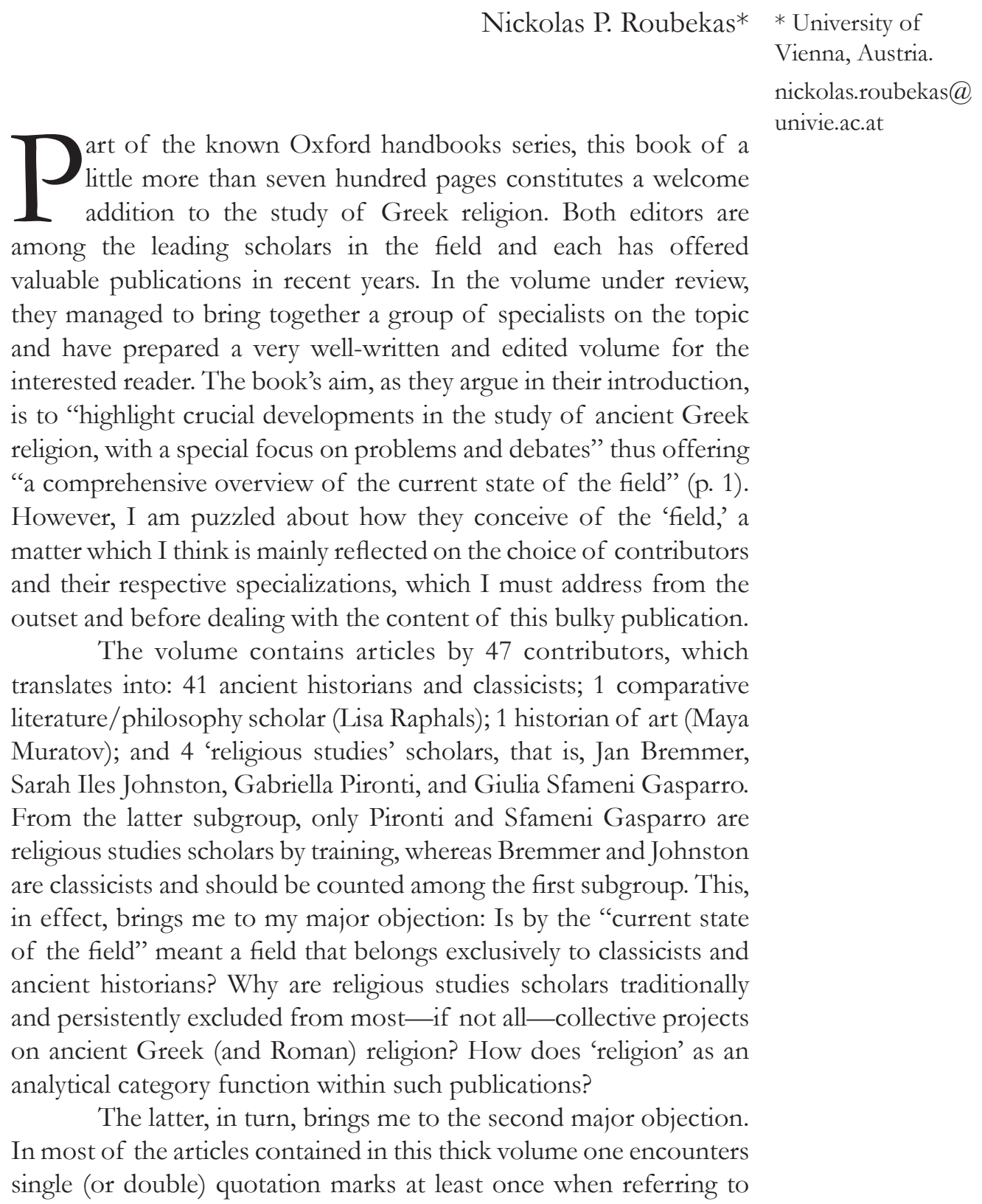


'religion' or 'Greek religion.' However, nowhere, let alone in the introductory chapter, is the reader given the/a reason behind this choice, although it is evident that something is meant, presumably of great significance. Such a choice that goes unexplained can only confuse the reader. I have failed to encounter anywhere in the volume a theoretically and methodologically sound reason that would explain why such a pattern is found throughout the book. If by the insertion of the quotation marks the authors mean that the term is problematic, then they should explain how and why it is so. If, on the other hand, they simply point out here the obvious anachronism at work, then, with few exceptions, they nevertheless go on and treat the topic as if there is no anachronism at work whatsoever. Finally, if the editors espouse such a choice — and I can see no reason why they should not - then why not add the quotation marks at the title of the volume as well and offer an explanation in the introduction?

The volume is divided into nine parts. The first part, "What is Ancient Greek Religion?" (p. 11-47), is comprised of 4 chapters. Normally, one would expect either a rudimentary or a detailed definition as an answer to this fundamental question which, however, is not to be found in this or in any of the other parts of the volume. For example, Robin Osborne's chapter, "Unity vs. Diversity," dedicates a mere few lines to the issue in the beginning where he argues that " $[\mathrm{t}]$ he term 'religion' cannot be translated into Greek. The Greeks knew that different people worshipped different gods and did so in different ways... But no Greek writer known to us classifies either the gods or the cult practices into separate "religions"' (p. 11). Although most scholars would agree with such a statement, I cannot see how this answers the main question of this first part of the book, or how it adds anything to the discussion of the term's genealogy and applicability. ${ }^{1}$ The claim of "challenging the very term 'religion' itself," as the editors put it when presenting Osborne's chapter in their introduction (p. 2) is hardly justified from a religious studies perspective. On the other hand, the interested reader will be rewarded by Thomas Harrison's chapter on "Belief vs. Practice" and his position that "we need, arguably, to emancipate ourselves further from the long legacy of the study of Greek religion, with its false choice of ritual and belief, and to accept the sphere of religious 'belief' as a more significant aspect in the study of Greek religious experience" (p. 27). It is, in my view, extremely important to leave behind the long tradition of seeing Greek religion as solely a ritualistic phenomenon and to concentrate equally on the motivation(s) behind ritual practices. Emily Kearns' chapter on "Old vs. New" and the chapter by Vientiane Pirenne-Delforge and Gabriella Pronto on "Many vs. One" conclude this important part of the book. Kearns offers a nice discussion on the various aspects of change and continuity, thus denoting the fluidity of ancient Greek religion, whereas PirenneDelforge and Pronto tackle the topic of polytheism. An objection here, however, is that the treatment of either polytheism or monotheism is not also accompanied by a discussion of the meaning of theós in this context. In other words, even if "a god can be seen as a complex network or cluster of powers," that is, as "defined by his or her own powers, competences,

\footnotetext{
${ }^{1}$ Although I might have missed it, I could not find in any of the individual chapters the very important recent publication by Nongbri, Brent, Before Religion: A History of a Modern Concept. New Haven, CT: Yale University Press, 2013.
} 
attributes, and so on" as well as "by [his or her] relationships and associations with other gods belonging to the same pantheon" (p. 40), this does not simultaneously mean that the problem - probably insurmountable — of what a theós is, before the conceptualization and establishment of a pantheon, is also covered in an adequate way.

In part two, "Types of Evidence" (p. 51-147), a number of categories are discussed in 6 chapters, including material evidence, prose, poetry, epigraphy, and papyrology. Although these are solid contributions that readers will appreciate, the ease with which ideas such as the embeddedness of religion in Greek society, or terms like sacred and secular are employed, creates further theoretical problems. A representative instance of such a choice can be found in Claire Taylor's chapter on "Epigraphic Evidence": "Because there was no separation between 'sacred' and 'secular' in the ancient Greek world in the post-Enlightenment sense, and because religious activity was embedded into all aspects of Greek life, almost all forms of epigraphic evidence tell us something, direct or indirect, about 'Greek religion”' (p. 97). One would expect at least an explanatory note on how these ideas are perceived by either Taylor or the ancient Greeks themselves (if such a case can be made).

Part three, "Myths? Contexts and Representations" (p. 151-224), is comprised of 5 chapters dealing with various kinds of literary works, such as epic, art, drama, history, and philosophy. These are very good discussions-I'd like here to highlight Robert Fowler's chapter on "History"- -although I am quite skeptical on how philosophy in connection to religion is treated by Rick Benitez and Harold Tarrant. For example, they "suggest that the philosophy-religion dichotomy has acquired some of its plausibility from scholars who first misunderstand the nature of religion, and, second, draw their concept of ancient philosophy too narrowly" (p. 222) without offering an answer to the unresolved question of what that 'nature of religion' is. Implying that religion does have a nature (or an 'essence'), they merely contribute to ongoing debates that remain unresolved. Perhaps their treatment of this topic could benefit from some of the recent publications stemming from religious studies scholars. ${ }^{2}$

Part four, "Where?" (p. 227-289), deals in 4 nicely written chapters with the locale of ancient Greek religion, including households, temples, community, and regional entities. Similarly, the 4 chapters found in part five, "How?" (p. 293-352), address multifaceted topics, such as religious expertise, introducing new gods, impiety, and law. Here, I must mention the very good chapters on the latter two topics by Hugh Bowden and Andrej Petrovic, respectively. Bowden's piece is an excellent introduction to the problem of impiety, whereas Petrovic makes sure to stress the problematic nature of the combination of terms such as 'sacred' and 'law.'

Of particular interest is part six, "Who?" (p. 355-443), which covers in 6 chapters perhaps the most difficult topics in the study of Greek religion, such as the gods and their nature, heroes, death, demons, and deification of humans. I should here mention Carolina López-Ruiz's chapter on "Gods-Origins," where she offers a very good postmodern approach

\footnotetext{
${ }^{2}$ For example, Schilbrack, Kevin, Philosophy and the Study of Religions. Malden, MA and Oxford: WileyBlackwell, 2014.
} 
to the issue of origins. However, in theorizing origins, she does not address the issue of the underlying need for which gods originate in the first place. The emergence of divine beings is not a self-generated phenomenon but typically fulfils some kind of a need on the part of either the individual or the group. ${ }^{3}$ Of equal interest is part seven, "What?" (p. 447-518), which deals in 6 chapters with issues like prayer, sacrifice, divination, epiphany, and healing. Although I do have some objections about how these contributors choose to address some of these topics-e.g., Fred Naiden's insistence on abandoning the term 'sacrifice' and replacing it with 'offering' (p. 473), as if it were the term that creates the problem and not the accompanying ideas behind it or the scholarly preconceptions-the contributions here are of high quality.

Finally, parts eight ("When?" [p. 521-563] in 3 chapters) and nine ("Beyond?" [p. 567-665] in 6 chapters) offer a panorama of topics from life cycle, rites of passage, and afterlife, to the expansion of Greek religious ideas outside the (fluid, one must say) limits of the Greek world. For the scholar of Greek religion, these chapters constitute very important studies that demonstrate the continually changing form and content of ancient religious ideas and their ability to penetrate and expand onto other cultures as distant as India and Bactria.

This nicely written volume concludes with two long indices: a general index (p. 667-691) and an index of passages (p. 693-708). For some scholars, the addition of a general bibliography is necessary, but I find the choice to include bibliographical references at the end of each chapter more functional in such a hefty volume.

The volume will be of great interest to students and scholars of the ancient world in general and Greek religion in particular. In my view, this fascinating field belongs to a wider range of scholarly voices than to classicists and ancient historians alone. I think that Henk Versnel's concluding remark in his chapter on "Prayer and Curse" nicely summarizes the issue: "[t] he notions covered by our terms do not always precisely correspond with the notions covered by the Greek words... [T] he profit of our exercises may consist of a modest contribution to a growing insight into the questions in what respects, to which degree, under which circumstances, and how distinctively Greeks, and, above all, which Greeks, conceived their world in ways different or similar to those of us moderns" (p. 459). Such an idea, in my view, cannot be fully covered by one specific discipline.

\footnotetext{
${ }^{3}$ See, for example, Segal, Robert A. "Theories of Religion." In The Routledge Companion to the Study of Religion, edited by John Hinnells, 49-60. London and New York: Routledge, 2005.
}

Recebido em: 5 de dezembro de 2016

Aprovado em: 27 de dezembro de 2016 